\title{
Philology Matters!
}

Essays on the Art of Reading Slowly

\author{
Edited by
}

Harry Lönnroth

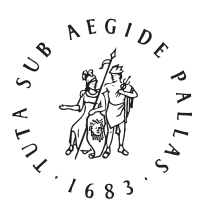

B R I L L

LEIDEN | BOSTON

For use by the Author only | (C) 2017 Koninklijke Brill NV 


\section{Contents}

Acknowledgements VII

List of Figures VIII

List of Tables IX

Notes on the Contributors $\mathrm{X}$

Introduction: Why Philology Matters XIV

Harry Lönnroth

$1 \quad$ Philology and the Problem of Culture 1

Helge Jordheim

2 Description and Reconstruction: An Alternative Categorization of Philological Approaches 21

Maja Bäckvall

3 Intertextuality and the Oral Continuum: The Multidisciplinary

Challenge to Philology 35

Karl G. Johansson

4 Philological Virtues in a Virtual World 58

Marita Akhøj Nielsen

$5 \quad$ Philology as Explanation for Historical Contexts 75

Jonas Carlquist

6 Romance Philology between Anachronism and Historical Truth: On Editing Medieval Vernacular Texts 97

Lino Leonardi

$7 \quad$ Levels of Granularity: Balancing Literary and Linguistic Interests in the Editing of Medieval Texts 118

Odd Einar Haugen

8 The Philology of Translation $\quad 136$

Harry Lönnroth and Nestori Siponkoski

For use by the Author only | (c) 2017 Koninklijke Brill NV 
9 Translating and Rewriting in the Middle Ages: A Philological Approach 164

Massimiliano Bampi

$10 \quad$ Ludwig Traube and Philology $\quad 182$

Outi Merisalo

Bibliography 197

Index 218

For use by the Author only | (C) 2017 Koninklijke Brill NV 


\title{
Translating and Rewriting in the Middle Ages: A Philological Approach
}

\author{
Massimiliano Bampi
}

\section{1 Introduction}

Translation has no doubt played a major role in the shaping and subsequent development of vernacular literatures in medieval Europe. As a consequence, the investigation of translation activities is a major concern of medieval studies around the world, as evidenced by the increasing body of scholarship produced in a variety of languages. ${ }^{1}$ The range of works in the field of translation studies has been progressively enriched, over the last twenty years, by the discussion aroused by the introduction of a new perspective on translation. Broadly speaking, a major turning point in this avenue of research can be traced back to the early 1990s, when translation began to be seriously approached, and examined, from a descriptive perspective rather than from a prescriptive one. ${ }^{2}$ In earlier work, the act of translation was indeed assessed mostly in terms of how faithful the target text was to the source text. The major consequence of adopting the criterion of fidelity as the exclusive measure is that most investigations tended to leave out any consideration of the context into which the text was imported. The advent and subsequent development of Descriptive Translation Studies (also known as Translation Studies), introduced a reconceptualization of translation as a complex semiotic phenomenon. In this view, translation is a process that entails, to varying degrees, a rewriting of the source text driven

1 Of particular relevance are The Medieval Translator volumes, published from 1989 to the present, which "set the tone for much subsequent scholarship." Emma Campbell and Robert Mills, Rethinking Medieval Translation: Ethics, Politics, Theory (Cambridge, 2012), p. 8. A useful discussion of most of the major publications in the field of medieval translation studies from the early 199os onward is provided by Campbell and Mills, Rethinking Medieval Translation, pp. 8-16. Among such publications, Rita Copeland's ground-breaking work certainly deserves special mention. Rita Copeland, Rhetoric, Hermeneutics, and Translation in the Middle Ages: Academic Traditions and Vernacular Texts (Cambridge, 1991).

2 On the prescriptive approach to translation, see Edwin Gentzler, Contemporary Translation Theories (Cleveland, 1993). 
first and foremost by the constraints of the target culture. From the viewpoint of the descriptive perspective, then, the translated text comes to be understood mainly as a part of the receiving culture. ${ }^{3}$ Accordingly, the characteristics of the target context receive adequate attention as they provide the frame within which the translation process takes place.

In the words of Susan Bassnett, one of the most prominent advocates of the descriptive stance,

[t]he purpose of translation theory, then, is to reach an understanding of the processes undertaken in the act of translation and, not, as is so commonly misunderstood, to provide a set of norms for effecting the perfect translation. ${ }^{4}$

Polysystem theory, developed by the Israeli scholar Itamar Even-Zohar starting in the mid-197os made a major contribution to the development of the descriptive approach to translation. ${ }^{5}$ With respect to translation, the main assumption of this theory is that translated texts should be viewed as playing a role in the shaping and development of a given literature. This role can, under certain circumstances, even be an innovative one, as will be shown below. Viewed from this perspective, translations cease to be considered as intrinsically inferior to original texts, and come to be understood as agents that actively take part in the growth and development of a literary system, both synchronically and diachronically.

In addition to Even-Zohar's seminal contribution, Gideon Toury's work on the role of norms in the target culture has also proved central to our understanding of the translator's attitude toward the text:

A translator may subject him-/herself either to the original text, with the norms it has realized, or to the norms active in the target culture, or, in that section of it which would host the end product. If the first stance is adopted, the translation will tend to subscribe to the norms of the

3 On the major tenets of Descriptive Translation Studies, see especially Gideon Toury, Descriptive Translation Studies and Beyond (Amsterdam, 1995).

4 Susan Bassnett, Translation Studies (London, 1991), pp. 37-38.

5 The polysystem theory is illustrated in Itamar Even-Zohar, "Polysystem Studies," Poetics Today 11 (1990), 1-251. For a brief introduction, see also Jeremy Munday, Introducing Translation Studies: Theories and Applications, 2nd ed. (London, 2008), pp. 108-110, and Mark Shuttleworth, "Polysystem Theory," in Routledge Encyclopedia of Translation Studies, eds. Mona Baker and Kirsten Malmkjær (London, 1998), pp. 176-179. 
source text, and through them also to the norms of the source language and culture. (...) If, on the other hand, the second stance is adopted, norms systems of the target culture are triggered and set into motion. Shifts from the source text would be an almost inevitable price. Thus, whereas adherence to source norms determines a translation's adequacy as compared to the source text, subscription to norms originating in the target culture determines its acceptability. Obviously, even the most adequacy-oriented translation involves shifts from the source text. ${ }^{6}$

The view of translation as a creative process that involves rewriting proves useful when it comes to analysing medieval translation, especially as regards literary texts. André Lefevere, one of the most prominent advocates of the descriptive approach, describes translation as an act of rewriting "undertaken in the service of power."

Given the multiform nature of translation activity as is known through manuscript evidence, it would certainly be pointless to seek a unique pattern common to any translation. With this caveat in mind, the kind of approach promoted by descriptive translation studies, including polysystem theory, is useful in disclosing properties of the target text that would otherwise go unnoticed or even misinterpreted, as will be shown below.

Despite this premise, however, attempts at using the methodological frame briefly described above for the investigation of medieval translations are still relatively small in number. ${ }^{8}$ Although discussing the reasons for this is outside of scope of this chapter, I think it is safe to claim that a certain degree of resistance to applying modern translation theories to medieval texts is likely to have contributed a considerable deal to muffling the impact of this kind of approach for some time. ${ }^{9}$ Still, in some major areas of medieval studies, most notably Middle English and Old French, other theoretically oriented approaches to translation practices have secured a firm place in scholarly discussion, as recent publications demonstrate. ${ }^{10}$

6 Toury, Descriptive Translation Studies and Beyond, p. 56.

7 André Lefevere, Translation, Rewriting, and the Manipulation of Literary Fame (London, 1992), p. vii.

8 A very early example of the application of polysystem theory to medieval translation and its role in the cultural system of twelfth-century France is provided by Maria Tymoczko, "Translation as a Force for Literary Revolution in the Twelfth-Century Shift from Epic to Romance," New Comparison 1 (1986), 7-27.

$9 \quad$ See Ruth Evans, “Translating Past Cultures?," in The Medieval Translator 4, eds. Roger Ellis and Ruth Evans (Exeter, 1994), especially pp. $25^{-26 .}$

10 Campbell and Mills, Rethinking Medieval Translation. 
In his preface to the 1990 issue of Speculum, which paved the way for further discussion on the role of philology in modern scholarly debate, Stephen G. Nichols observes that

a rethinking of philology should seek to minimize the isolation between medieval studies and other contemporary movements in cognitive methodologies, such as linguistics, anthropology, modern history, cultural studies, and so on, by reminding us that philology was once among the most theoretically avant-garde disciplines. ${ }^{11}$

What is under discussion here is clearly not the uncritical application of any modern theory to the medieval text. The fact that the descriptive approach to translation fully acknowledges the importance of considering translation as an historical concept represents a relevant condition for its applicability to medieval translated texts. As Even-Zohar puts it,

(...) even the question of what is a translated work cannot be answered $a$ priori in terms of an a-historical out-of-context idealized state: it must be determined on the grounds of the operations governing the polysystem. Seen from this point of view, translation is no longer a phenomenon whose nature and borders are given once and for all, but an activity dependent on the relations within a certain cultural system. ${ }^{12}$

Such an approach allows us to view translation in its multifaceted and changing nature, opening up to forms of textual manipulation that a normative approach would otherwise not contemplate. The range of translational practices from the medieval period, in which translation very often took the form of a rewriting of the source text, especially in the case of anonymous narrative texts, can thus be usefully approached from the perspective of polysystem theory.

The aim of this chapter is to show that the descriptive approach to translation developed over the last twenty years can be fruitfully applied to medieval translation only in conjunction with the adoption of a philological perspective, one that foregrounds the peculiarities of medieval textual production and seeks to tackle the interpretive problems that a manuscript culture poses to modern scholars. A long and multifaceted discussion of the nature of philol-

\footnotetext{
11 Stephen G. Nichols, "Introduction: Philology in a Manuscript Culture: Thoughts on the Discipline," Speculum 65 (1990), 1.

12 Even-Zohar, "Polysystem Studies," 51.
} 
ogy within the humanities has made clear that philology can be described and defined in a variety of ways, depending on the angle from which it is considered. $^{13}$

If we understand philology as Textwissenschaft, 'the science of text,'14 i.e. an historical discipline that aims at both restoring texts and interpreting them from within the context in which they were produced and disseminated, its role in the present context is at least twofold. First, it sets the boundaries of theoretical discourse and frames it by foregrounding the materiality of manuscript evidence as the inevitable point of departure and arrival of any kind of speculation around texts that are remote in time (and place). Second, by drawing attention to the context in which texts emerge-i.e. the linguistic and social context as well as the codicological environment of a text - philology contributes to seeking information-whenever this is possible-about the context of use of texts (e.g. the recipient of the text, its commissioner, and the socio-cultural milieu in which the text was used). Knowing for whom a text was translated, and for what kind of purpose, is indeed essential in seeking to reconstruct and assess the translation process. In addition, philology makes us aware of the limits of using critical editions for the analysis of the translation, as will be shown below.

In the interplay between philology and modern translation theory, the latter proves useful in that it provides general principles that can shed light on relevant aspects of the translated text as a rewrite of a source text. ${ }^{15}$ But more

13 See for example Paul de Man, "Return to Philology," in The Resistance to Theory, foreword Wlad Godzich (Manchester, 1986), pp. 21-26; Jan Ziolkowski, ed., On Philology (University Park, 199o); Odd Einar Haugen, "Fem argument mot filologien," [Five arguments against philology] in Den fornnordiska texten i filologisk och litteraturvetenskaplig belysning, eds. Kristinn Jóhannesson, Karl G. Johansson, and Lars Lönnroth (Gothenburg, 2000), pp. 1726; Edward W. Said, Humanism and Democratic Criticism (New York, 2004); Sheldon Pollock, "Future Philology? The Fate of a Soft Science in a Hard World," Critical Inquiry 35 (2009), 931-961; Harry Lönnroth, “Filologi i Facebooks tidevarv—vad, hur och varför?," [Philology in the age of Facebook—what, how, and why?] in Studier i svensk språkhistoria 13, eds. Daniel Andersson et al. (Umeå, 2016), pp. 31-49.

14 See especially Zeitschrift für deutsche Philologie 116 (1997) with the theme "Philologie als Textwissenschaft: Alte und Neue Horizonte."

15 Much more controversial is the use of theory as proposed by Lynne Long, "Medieval Literature through the Lens of Translation Theory: Bridging the Interpretive Gap," Translation Studies 3 (2010), 61-77. In her article, she claims that "theories used in the modern discipline of translation studies can in fact be usefully employed both by medievalists and translation scholars to highlight the translation possibilities in the layers of text without depending on detailed historical research," p. 62 (my italics). The reason for this is that, according to her, "the discipline of translation studies intends to theorize the process of 
importantly, theory helps pose questions and makes it possible to approach a problem from different (and most often novel) angles.

The following sections discuss examples taken from medieval Nordic culture to make these points.

When compared to other areas of study, Old Norse scholarship has long seemed to be more reluctant, or less attuned, to adopting a theoretical stance on translation studies. ${ }^{16}$

In recent years, however, some studies devoted to translation practices in medieval Scandinavia have begun to mark a turning point in that they engage with translation theory to carry out their analyses. ${ }^{17}$

In his seminal article on the translated riddarasögur ('sagas of knights,' or 'chivalric sagas'), Jürg Glauser was among the first to point out the importance of promoting an approach to translation that views it as a rewriting process:

[T] he concept of medieval translation as rewriting, as applied with great success to Njáls saga by Jón Karl Helgason (1999), represents a method that can be used as a basis on which to proceed. In fact, rewritingthought of as continuation, writing anew, paraphrasing, etc.-is precisely the word to describe the phenomena that also define the sagas of

translation whenever they occur, employing paradigms that work whatever the context," p. 62. Long's claims clearly suggest the supremacy of theory over its usefulness as an instrument for better understanding and assessing the characteristics of a medieval translated text. Indeed, claiming that knowledge of the specificities of the historical context is not necessary entails assigning to theory an absolute value.

16 The term Old Norse is here used to include both East (i.e. Old Swedish and Old Danish) and West Norse (Old Icelandic and Old Norwegian) literary and linguistic traditions.

17 See e.g. Massimiliano Bampi, "Translating Courtly Literature and Ideology in Medieval Sweden: Flores och Blanzeflor," Viking and Medieval Scandinavia 4 (2008), 1-14; Jonatan Pettersson, Fri översättning i det medeltida Västnorden [Free translation in medieval West Nordic society] (Stockholm, 2009); Sofia Lodén, Le chevalier courtoise à la rencontre de la Suède médiévale (Stockholm, 2012); Sif Rikhardsdottir, Medieval Translations and Cultural Discourse: The Movement of Texts in England, France and Scandinavia (Cambridge, 2012); Suzanne Marti, "King Arthur's Journey North: Translation in Medieval Norway," Translation Studies 6 (2013), 19-32; Stefka Eriksen, Writing and Reading in Medieval Manuscript Culture: The Translation and Transmission of the Story of Elye in Old French and Old Norse Literary Contexts (Turnhout, 2014). 
knights. In evaluating the translation performance of these sagas, such an approach would be highly advantageous, enabling literary translations to be viewed within the framework of such a concept as part of a process of cultural appropriation, and as contributing to a discussion in the recipient culture of what that culture perceives as foreign. This would be a very much more productive approach to the phenomena that need to be described in this connection than an argumentation using such terms as 'exact'/'correct' vs. 'inexact'/'incorrect', etc. ${ }^{18}$

The case of the translated riddarasögur mentioned by Glauser provides a very good example for illustrating the advantages of adopting such an approach.

The translated riddarasögur comprise translations of chivalric works, mostly from Old French and Anglo-Norman sources, into Old Norse. It is commonly believed that most translations were produced at the instigation of King Hákon IV Hákonarson, who reigned over Norway from 1217 to 1263. For a long time, these texts were examined from a strictly prescriptive viewpoint. Paul Aebischer's and Eyvind Fjeld Halvorsen's works on the Old Norse Karlamagnús saga are a case in point. ${ }^{19}$ Both scholars expressed criticism of the quality of the translation compared to their source texts, thus casting doubts on the translator's ability to understand the subtleties of the Old French texts. Although more recent studies have rejected the conclusions reached by these two scholars, some weighty preconceptions regarding the quality of the translated riddarasögur within the context of the saga literature have continued to influence the approach to this genre. ${ }^{20}$ Indeed, even when the attention began to gradually shift to the transformations that the source texts underwent in the transition to the target culture, the observations often had a negative slant, as pointed out by Glauser. ${ }^{21}$

The fact that translated texts are now increasingly considered as a "fact of the target system"22 and are examined as such, allows us to delve more deeply into the texts themselves, focussing on textual evidence that reveals the kind of

18 Jürg Glauser, "Romance (Translated riddarasögur)," in A Companion to Old Norse Icelandic Literature and Culture, ed. Rory McTurk (Oxford, 2005), pp. 381-382.

19 Paul Aebischer, Les versions norroises du 'Voyage de Charlemagne en Orient' (Paris, 1956); Eyvind Fjeld Halvorsen, The Norse Version of The Chanson de Roland (Copenhagen, 1959). See, e.g., Jonna Kjær, “La réception scandinave de la littérature courtoise et l' exemple de la Chansonde Roland/Af Rúnzivals bardaga: Une épopée féodale transformée en roman courtois?," Romania 114 (1996), 62-68.

21 Glauser, "Romance (Translated riddarasögur)," p. 380.

22 Lawrence Venuti, The Translation Studies Reader (London, 2000), p. 149. 
adaption the texts went through during the translation process. ${ }^{23}$ Theory, however, has necessarily to cope with the historical and cultural specifics of the period from which the texts-in this case the translations-originate. In the case of the translated riddarasögur, for example, we must bear in mind that these texts are known to us almost exclusively through later Icelandic copies, produced in the fourteenth and fifteenth centuries. ${ }^{24}$ As matters now stand, we are therefore not able to establish whether the deviations found in the Old Norse texts are innovations made by the translator, or whether they should be attributed to the Icelandic copyist. Indeed, both the copying and the translation processes open up the text to various forms of manipulation/variation, driven by the constraints of the receiving context. Knowledge of the two social and cultural contexts in which they were circulated-i.e. the thirteenth century in Norway, or the fourteenth and fifteenth centuries in Iceland-is no doubt of paramount importance in order to seek to assign the novelties in the translation to either the translator or the scribe. However, even if a given change might be explained from within the context in which the text is known-or believed - to have been produced, we must acknowledge and be explicit about the possibility that the supposed innovation derives from a lost version of the text. Furthermore, quite often the same kind of textual change may well have been introduced in either context.

The interpretation of textual innovations in the translated texts is of course strictly related to the textual basis that is used to make the comparison. Given the status of medieval literary texts (especially the anonymous ones) as intrinsically unstable, ${ }^{25}$ adequate attention should be paid to manuscript variation.

23 On the translated riddarasögur as a genre, see in particular Karl G. Johansson and Else Mundal, eds., Riddarasögur: The Translation of European Court Culture in Medieval Scandinavia (Oslo, 2014), which contains a number of essays dedicated to various aspects of the transmission of the translated chivalric sagas. The surviving corpus of the Icelandic sagas is categorized using a taxonomy that has been established in a number of studies during the twentieth century. The sagas have accordingly been divided into a number of subgroups that are customarily referred to as genres. The two major criteria employed to devise the current taxonomy are the subject matter treated in the saga and the chronology. For an introduction to the saga genres, see Margaret Clunies Ross, The Cambridge Introduction to the Old Norse-Icelandic Saga (Cambridge, 2010), pp. 72-94.

24 Glauser, "Romance (Translated riddarasögur)," pp. 377-378.

25 Paul Zumthor, La lettre et la voix: De la "littérature" médiévale (Paris, 1987); Rikhardsdottir, Medieval Translations and Cultural Discourse, pp. 5-13. The term mouvance was coined by the Romance philologist Paul Zumthor to describe the instability of medieval texts throughout their manuscript transmission. In his own words the mouvance is "le caractère de l'œuvre qui, comme telle, avant l' âge du livre, ressort d' une quasi-abstraction, les textes 
It can be very misleading to rely on critical editions alone, which are based on reconstructive principles, to carry out the analysis of the underlying translation strategy of a riddarasaga text. Although the number of new editions of the texts belonging to this genre is growing, a good number of them is still known only through nineteenth-century editions, which are in general inadequate for the purpose of analysing the relationship between translations and their alleged source texts. ${ }^{26}$

The varying degree of reliability of an edition makes it therefore necessary for anyone conducting research on a medieval text-including researchers in translation studies - to be able to access it, and work with it, in its manuscript form(s). Since it is much more common to work using critical editions, scholars dealing with medieval translations should be aware of the limits of the restitutio textus in its reconstructive form, thus keeping the manuscript(s) as a constant point of reference in their interpretative work.

Viewing Translated Literature as a System

A major contribution that translation theory can make to our knowledge of the mechanisms governing the production and dissemination of texts-both original and translated - in the Middle Ages is provided by polysystem theory.

Rooted in Russian formalism and in Czech poststructuralism, this theory was developed by Even-Zohar in a number of articles published from the late 1970s to the early 199os. The term polysystem is used to describe "a heterogeneous, hierarchized conglomerate of systems which interact to bring about an ongoing, dynamic process of evolution within the polysystem as a whole." ${ }^{27}$ In other words, the elements that make up the polysystem compete with each other for the dominant position, and bring about a distinction between centres and peripheries. In the case of the literary polysystem, each genre can be said to correspond to a system. Translated literature is one of such systems, and as such it is part of the interaction with original texts.

Though translated literature tends to be a peripheral system, being subject to the influence exerted by central systems, Even-Zohar identifies three sets of circumstances where it occupies a primary position:

concrets qui la réalisent présentant, par le jeu des variantes et remaniements, comme une incessante vibration et une instabilité fondamentale." Zumthor, La lettre et la voix, p. 610. Glauser, "Romance (Translated riddarasögur)," p. 378.

27 Shuttleworth, "Polysystem Theory," p. 177. 
1) When a polysystem has not yet been crystallized, that is to say, when a literature is "young," in the process of being established;

2) When a literature is either "peripheral" (within a large group of correlated literatures) or "weak," or both;

3) When there are turning points, crises, or literary vacuums in a literature. ${ }^{28}$

The implications of this model for our understanding of medieval translation are far-reaching: They allow us to overcome the traditional view that translations do not play as prominent a role in the development of a literary system as original texts. When translation assumes a prominent position in the literary polysystem, it exerts a direct influence on both the composition of new original works and on other translations. In Even-Zohar's own words, "it participates actively in shaping the center of the system." ${ }^{29}$ Furthermore, when translation plays such a primary role, the boundaries between original works and translated texts tend to fade, and the definition of translation becomes freer in that it comes to include imitations and adaptations. ${ }^{30}$

Polysystem theory is very helpful in explaining the role of the translated riddarasögur in the development of the literary polysystem of medieval Iceland, especially with regard to sagas. ${ }^{31}$ It is a commonly accepted view that after the annexation of Iceland to Norway, which took place in 1262-1264, the writing of sagas was marked by a turn to the fantastic. Manuscript evidence does indeed indicate that the literary system of the fourteenth and fifteenth centuries is characterised by a prominence of genres such as the riddarasögur (both translated and original) ${ }^{32}$ and the fornaldarsögur (especially the more fantastic Abenteuersagas), in which the fantastic and the exotic are prominent features. These genres even came to exert an influence on the

28 Even-Zohar, "Polysystem Studies," 47.

29 Even-Zohar, "Polysystem Studies," 46.

$30 \quad$ Even-Zohar, "Polysystem Studies," 51.

31 Jonatan Pettersson, "Riddarasögur in the North-Atlantic Literary Polysystem of the Thirteenth Century: The Value of a Theory," in Riddarasögur:The Translation of European Court Culture in Medieval Scandinavia, eds. Karl G. Johansson and Else Mundal (Oslo, 2014), pp. 107-127.

32 These texts were crafted in Iceland, partly following the model of the translated sagas of knights and the more adventurous of the fornaldarsaga texts, i.e. the Abenteuersagas. The settings are for the most part exotic and fantastic. For an introduction, see Jürg Glauser, Isländische Märchensagas: Studien zur Prosaliteratur im spätmittelalterlichen Island (Basel, 1983), and Geraldine Barnes, The Bookish Riddarasögur: Writing Romance in Late Medieval Iceland (Odense, 2014). 
younger representatives of the more realistic genre (the Íslendingasögur, or 'Sagas of Icelanders'), which has long been considered the hallmark of saga writing. ${ }^{33}$

Polysystem theory helps to explain literary facts as resulting from the interplay between the literary and the social systems. The period following the annexation to Norway was a turning point, from a social and political as well as literary viewpoint, which, as seen above, is one of the circumstances under which translation comes to play a major innovative role in the literary system. ${ }^{34}$ The translated riddarasögur served to consolidate a new set of values that was imported into Old Norse culture at the beginning of the thirteenth century. As Helgi Pórlaksson points out, for example, by 1200 Icelandic chieftains "adopted the customs of foreign noblemen in their dress and weaponry, and coveted beautiful objects and luxury goods from abroad." ${ }^{35}$ Thus, the interest in kinship and in courtly ideology, as well as in the material aspects of the new culture, which began to grow in Norway did so in Iceland too, promoting the copying of the riddarasögur translated at the instigation of King Hákon Iv Hákonarson. The fact that the generic markers characterizing the translated riddarasögur in terms of fictional worlds and narrative patterns can be found in other genres of saga literature shows that the new genre came to occupy the centre of the literary polysystem. ${ }^{36}$ This was made possible because those who commissioned the translation and copying of such sagas (the so-called canonizing agencies, in Even-Zohar's terms) belonged to the highest social strata in Norway (the king) and Iceland (the chieftains and rich people), i.e. those at the very hub of the social and political systems. ${ }^{37}$

Another relevant example that shows the advantages of applying modern theories in the field of translation is that of medieval Sweden. The literature

33 On the whole question, see Massimiliano Bampi, "Literary Activity and Power Struggle: Some Observations on the Medieval Icelandic Polysystem after the Sturlungaöld," in Textual Production and Status Contests in Rising and Unstable Societies, eds. Massimiliano Bampi and Marina Buzzoni (Venice, 2013), pp. 59-70.

34 Bampi, "Literary Activity and Power Struggle."

35 Helgi Pórlaksson, "Social Ideas and the Concept of Profit in Thirteenth-Century in Iceland," in From Sagas to Society: Comparative Approaches to Early Iceland, ed. Gísli Pálsson (Enfield Lock, 1992), p. 234.

36 See Bampi, "Literary Activity and Power Struggle," pp. 62-63.

37 On the political meaning of the translated riddarasögur, see, for example, Jürg Glauser, "Vorbildliche Unterhaltung: Die Elis saga ok Rósamundu im Prozeß der königlichen Legitimation," in Applikationen: Analysen skandinavischer Erzähltexte, ed. Walter Baumgartner (Frankfurt am Main, 1987), pp. 95-129; Susanne Kramarz-Bein, Die Piðreks saga im Kontext der altnorwegischen Literatur (Tübingen, 2002), pp. 108-114. 
written in Old Swedish has long been neglected in international scholarship on the grounds that it consists mostly of translated texts, and was therefore deemed inferior to the rich and highly original literary production of medieval Iceland.

The adoption of an approach based on both polysystem theory and descriptive translation studies has progressively contributed to a re-evaluation of the vernacular textual production in medieval Sweden. Recent studies have begun to address the question of the role played by translations in the development of the literary system of medieval Sweden, as well as their use in shaping the cultural and social identity of the Swedish aristocracy. ${ }^{38}$

In particular, the nature and role of the Eufemiavisor [Eufemia's lays] have been investigated in depth. ${ }^{39}$ The Eufemiavisor are indeed the first example of literary production in the vernacular in Sweden in the Middle Ages. Some of the aforementioned studies deal with the Eufemiavisor individually. Massimiliano Bampi and Sofia Lodén respectively examined Flores och Blanzeflor and Herr Ivan lejonriddaren. ${ }^{40}$ Both studies share the same focus on the forms of cultural appropriation that the analysis of the translation strategies reveals. Furthermore, given the uncertainty surrounding the nature of the source texts used by the Swedish translator(s), both investigations call for interpretive caution when assessing the peculiarities of the translated texts against both the Old Norwegian and the Old French traditions. ${ }^{41}$

In her study, Lodén comes to the following conclusion:

38 Massimiliano Bampi, The Reception of the Septem Sapientes in Medieval Sweden between Translation and Rewriting (Göppingen, 2007); Massimiliano Bampi, "Translating Courtly Literature and Ideology in Medieval Sweden;" Thomas Småberg, "Bland drottningar och hertigar: Utblickar kring riddarromaner och deras användning i svensk medeltidsforskning," [Among queens and dukes: Perspectives on romances of chivalry and their use in Swedish medieval studies] Historisk tidskrift 131 (2011), 197-226; Lodén, Le chevalier courtoise à la rencontre de la Suède médiévale.

39 The name Eufemiavisor is customarily used to refer to three Old Swedish translations of chivalric literature (Herr Ivan lejonriddaren, Hertig Fredrik av Normandie, and Flores och Blanzeflor) that were made in the early fourteenth century at the instigation of the Norwegian queen Eufemia. For an introduction, see William Layher, Queenship and Voice in Medieval Northern Europe (New York, 2010), pp. 91-99.

40 Bampi, "Translating Courtly Literature and Ideology in Medieval Sweden;" Lodén, Le chevalier courtoise à la rencontre de la Suède médiévale.

41 On the question of the sources, see Bampi, "Translating Courtly Literature and Ideology in Medieval Sweden," 2-4, and Lodén, Le chevalier courtoise à la rencontre de la Suède médiévale, pp. 38-42. 
Instead of considering Herr Ivan as a free or close translation, it is argued that it should be seen as a coherent and engaged interpretation that does not misinterpret its sources but interprets them for the sake of intrinsic coherence. Whereas the notion of courtoisie is highly ambiguous in Le Chevalier au lion, the translator chooses to give it a clear and distinct interpretation by highlighting the role of honour. ${ }^{42}$

Along the same lines, Bampi shows that most of the deviations in the Old Swedish text are likely to derive from the translator's intent to highlight some aspects of the story. Honour, for example, plays a major role in Flores och Blanzeflor too, especially with regard to the characterization of noble characters in the story. Let us take an example.

When the king of Babylon addresses the Christian princess Blanzeflor in a harsh way, in the Old Swedish text a censorious attitude is expressed by the words uttered by Flores, who has eventually been able to find her beloved, after a long search, imprisoned in a tower. Flores's words do not find any counterpart in either the Old French or the Old Norwegian versions of the story. Whereas in the latter versions the king refers to the woman as "whore" (Old French putain, Old Norwegian púta), in the Old Swedish text the passage reads as follows:

Example 1

Flores sagdhe til konungin tha:

"Talin the quinno ey illa op a

for idher eghin konungxlik cera

Hon ær ey værdugh skyld at bæra"

Flores said to the King:

"Do not speak so badly of this woman

on your royal honour

She does not deserve to be blamed"43

Given the didactic nature of the story — and, more in general, of the Eufemiavisor - the hypothesis that whoever translated the text made the change is quite likely. ${ }^{44}$

42 Lodén, Le chevalier courtoise à la rencontre de la Suède médiévale, p. 285.

43 The example and the translation are taken from Bampi, "Translating Courtly Literature and Ideology in Medieval Sweden," 9-10. My italics.

44 On this aspect, see Stephanie Würth, "Eufemia: Deutsche Auftraggeberin schwedischer 
Other similar instances of change are found throughout the Eufemiavisor. Valter Jansson, for example, noted a tendency in all three translations to enhance the nobility of the characters. ${ }^{45}$

What is more interesting, however, is that we find the same kind of aristocratic ideology that the three translated texts imported into medieval Swedish culture at work in later Swedish translations from other narrative works. A case in point is the so-called Sju vise mästare [Seven wise masters], a name customarily employed to define three different translations of a collection of short stories of Oriental origin known as The Seven Sages of Rome. The three extant translations (known as A, B, and c since G.E. Klemming's edition, published in 1887-1889) are based on three different source texts. ${ }^{46}$ The $\mathrm{C}$ redaction is particularly interesting in that it has been possible to establish with reasonable certainty that its source text is quite probably the Middle Low German version of the collection that Lucas Brandis printed in Lübeck in $1478 .{ }^{47}$

The Old Swedish translation is preserved in MS. AM 191 fol. (also known as Codex Askabyensis), a miscellany that was owned by the chaplain of the Cistercian nunnery at Askeby, in the province of Östergötland, around 1492. A note in the manuscript makes it clear that some of the texts-including Sju vise mästare - were written by the chaplain (fol. $49^{\mathrm{v}}$ ).

It is more than likely that the texts making up the collection-or at least some of them-were meant to address an aristocratic public. ${ }^{48}$ The hypothesis

Literatur am norwegischen Hof," in Arbeiten zur Skandinavistik 13, ed. Fritz Paul (Frankfurt am Main, 1999), p. 274. On the exemplary function of the Eufemiavisor, see Småberg, "Bland drottningar och hertigar," 212-221.

45 Valter Jansson, Eufemiavisorna: en filologisk undersökning [The Eufemiavisor: A philological study] (Uppsala, 1945), p. 47.

46 See Bampi, The Reception of the Septem Sapientes in Medieval Sweden between Translation and Rewriting.

47 Kurt Erich Schöndorf, "Die altschwedische Version c von Sju vise mästare und ihre mittelniederdeutsche Vorlage," in Niederdeutsch in Skandinavien III, eds. Lennart Elmevik and Kurt Erich Schöndorf (Berlin, 1992), pp. 49-69; Bampi, The Reception of the Septem Sapientes in Medieval Sweden between Translation and Rewriting, pp. 92-93. Lucas Brandis was one of the most important printers in Northern Germany during the second half of the fifteenth century. He worked primarily in Merseburg, Magdeburg and Lübeck. On his activity, see Ursula Altmann, Die Leistungen der Buchdrucker mit Namen Brandis im Rahmen der Buchgeschichte des 15.Jh.s (Berlin, 1974), http://edoc.hu-berlin.de/dissertationen/ altmann-ursula-1974-12-18/PDF/Altmann.pdf.

48 Bampi, The Reception of the Septem Sapientes in Medieval Sweden between Translation and Rewriting, pp. 34-39; Per-Axel Wiktorsson, Äktenskapsvisan:En lustig visa om samgåendets vedermödor [The marriage song: An amusing song about the troubles of cooperation] (Stockholm, 2007). 
that the chaplain used some of these texts for the moral edification of the nuns, ${ }^{49}$ who were most probably members of noble families, would explain some of the peculiar traits of the Old Swedish translation, as the following example illustrates:

Example 2

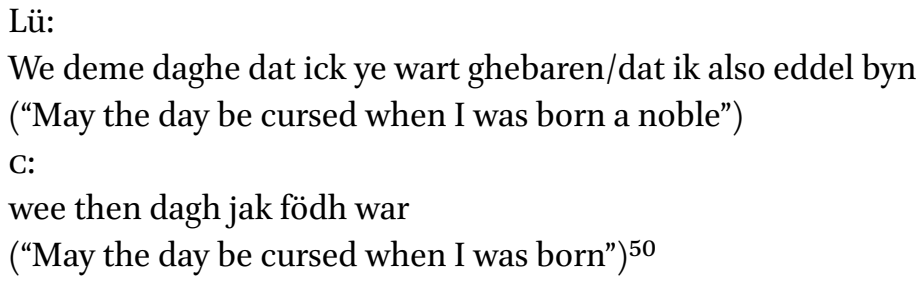

The words cited in example 2 above are spoken by the empress, who is described as a wicked and greedy woman. Whereas in the Middle Low German text (Lü) the empress curses herself when she realizes that her plans are failing, in the translated text the curse is omitted. If we accept the hypothesis, based on both textual and extratextual considerations, that the text was used as a collection of edifying exempla for the moral instruction of the noblewomen at Askeby, the absence of the curse is in all likelihood a deliberate omission on the part of the translator, who may have judged such a curse as inappropriate, given the high social status of the empress (and of the nuns as recipients of the story). This censorious attitude is similar to that observed with regard to the Eufemiavisor. Similar instances can be found throughout the text.

Especially remarkable in this context is that the translation strategy characterizing the Sju vise mästare and some other fifteenth-century translations (e.g. Namnlös och Valentin, 'Nameless and Valentine') is best viewed as a consequence of the Eufemiavisor still holding a central position in the Old Swedish literary polysystem. When the three texts were translated the literary polysystem was still young, i.e. taking shape. Therefore it is not surprising that the influence of the Eufemiavisor is obvious, at both the ideological and stylistic levels, in the shaping of the Erikskrönikan [The Chronicle of Duke Erik], a

49 Bampi, The Reception of the Septem Sapientes in Medieval Sweden between Translation and Rewriting, p. 38 .

50 Quoted from Massimiliano Bampi, "Translating and Rewriting: The Septem Sapientes in Medieval Sweden," in Rittersagas: Übersetzung — Überlieferung —Transmission, eds. Jürg Glauser and Susanne Kramarz-Bein (Tübingen, 2014), p. 244. More examples of this kind are discussed in Bampi, "Translating and Rewriting," pp. 243-244. 
verse chronicle composed in the early 1320 s that narrates the deeds of Swedish knights (on the Erikskrönikan, see also Lönnroth and Siponkoski's chapter in this volume). Like the Eufemiavisor, the Erikskrönikan surely had an aristocratic patronage, and was read aloud in an aristocratic milieu, as explicitly mentioned in the prologue. ${ }^{51}$

More interesting is the influence that the Eufemiavisor appear to have exerted on later translations, as the case of Sju vise mästare illustrates. The fact that two of the three redactions of Sju vise mästare (A and C) are preserved in manuscripts alongside either all three texts (Cod. Holm. D 4) or just one (AM 191 fol.) is no doubt relevant. The same holds true for Namnlös och Valentin, a fifteenth-century translation that appears in miscellanies that also preserve the Eufemiavisor (D 4 and D 3). In addition, the influence of the Eufemiavisor on both Sju vise mästare and Namnlös och Valentin is discernible also in terms of formulaic expressions. If we wish to account for why the Eufemiavisor are so influential even so long after coming into being, at the beginning of the fourteenth century, the polysystem theory proves very helpful. Knowledge of the manuscript's transmission and its social environment is of course extremely important. Most of the miscellanies preserving a large part of the texts in Old Swedish (Cod. Holm. D 3, Cod. Holm. D 4a, Cod. Holm. D 4, and AM 191 fol.) are indeed clearly linked to an aristocratic milieu. Three of the aforementioned manuscripts (D 3, D 4a, and D 4) are in all likelihood works commissioned by members of the same noble family, as recent studies have demonstrated. ${ }^{52}$

It should be no surprise, then, that the kind of courtly ideology introduced by the Eufemiavisor was kept alive in considerably younger texts, which were meant to address an aristocratic audience. In polysystemic terms, this was made possible also by the fact that the Eufemiavisor were not challenged by original texts in maintaining the central position in the literary polysystem. Unlike medieval Iceland, where the vitality of the saga genre produced original texts partly modelled after the translated riddarasögur, in Sweden translations appear to have satisfied the need for innovation.

51 Fulvio Ferrari, "Literature as a Performative Act: Erikskrönikan and the Making of a Nation," in Lärdomber oc skämptan: Medieval Swedish Literature Reconsidered, eds. Massimiliano Bampi and Fulvio Ferrari (Uppsala, 2008), pp. 55-80. till identifiering [The poet of the Erikskrönikan-An attempt to an identification] (Uppsala, 2010), p. 104. 
Examples 1-2 above demonstrate that the adoption of a theoretically oriented approach to translations from the medieval period helps highlight aspects of the text and its place in the literary polysystem that other approaches tend to overlook.

The shift from a prescriptive to a descriptive perspective draws attention to the role played by the norms obtaining in the receiving culture, thus foregrounding constraints of a kind that affects the translation process and its final outcome. This enables the deviations found in the translated text to be viewed against the backdrop of the target culture.

The polysystemic approach broadens the scope from the textual to the cultural level, leading to the view that the role translations play in the literary polysystem is a consequence of the interplay between the literary systems and other systems, most notably social systems. Even-Zohar's idea that the definition of translation depends on the dynamics operating at the level of the polysystem suggests that a broader view than the textual one must be adopted in order for a text to be properly understood, especially as regards its role in the receiving culture.

In this attempt at approaching and evaluating medieval translations as bearers of cultural difference, the role of philology as defined above is of great importance. As an art of reading slowly, philology helps us dig deep into the text in its materiality (i.e. first and foremost in its manuscript form) and also the context in which it was produced and used, looking for the kind of information that may be used to analyse the text as a rewrite. Thus it provides both textual and contextual evidence with which to further elaborate and refine the theory itself. Indeed, medieval translation has been almost ignored in the theoretical elaboration of the descriptive approach. Clearly, specific problems characteristic of medieval textual production and translation, as discussed in this chapter, must necessarily be tackled by a philologist, or by a philologically aware scholar. ${ }^{53}$ Taking a philological stance on the adoption of theory is also essential in terms of awareness of the limits of critical editions as a safe basis for comparison.

The cross-fertilization that the interplay of philology and modern theory is able to foster, in the field of translation studies as well as in other areas of inquiry with regard to the medieval period, is by and large still a potentiality.

53 On these questions, see Lönnroth, "Filologi i Facebooks tidevarv—vad, hur och varför?" 
Hopefully, future work combining philological preoccupation, methodological rigour and theoretical attentiveness will broaden the scope of our knowledge of the nature and role of translation in medieval Europe. 